\title{
Internal inguinal ring closure by laparoscopy using homologous pericardium grafts in horses
}

\author{
Oclusão do anel vaginal em equinos utilizando \\ enxerto de pericárdio homólogo fixado por laparoscopia
}

\author{
Julio David Spagnolo ${ }^{I^{*}}$ Idercio Luis Sinhorini $^{\text {II }}$ Raquel Yvonne Arantes Baccarin ${ }^{\text {III }}$ \\ Aline Magalhães Ambrosio ${ }^{I}$ Maria Teresa de Mello Souto ${ }^{I}$ Keila Kazue Ida \\ Luis Claudio Lopes Correia da Silva ${ }^{I}$
}

\section{ABSTRACT}

The occlusion of inguinal ring is the treatment to avoid the inguinal hernia in horses. The aim of this study is evaluate the efficacy of homologous pericardium grafts for internal inguinal ring closure in horses, comparing mechanical or manual laparoscopic suture. Cross over study, using six healthy intact male Mangalarga breed horses aged between 3 and 12 years. Horses were operated under general anesthesia in $25^{\circ}$ Trendelenburg position. Five laparoscopic portals were employed. Pericardium grafts measuring $4 \times 5 \mathrm{~cm}$ were anchored covering the left and right internal inguinal rings using either manual intracorporeal suture or laparoscopic stapler. Horses were followed-up during 11 weeks when were submitted to a laparoscopic control. Surgical time, trans and postoperative complications and effectiveness of internal inguinal closure were evaluated and statistically analyzed. The level of significance was set at $5 \% P<0.05$. The procedures were realized without complications and the mean time required for manual and mechanical suture procedures differed significantly $(67.8 \pm 15.3$ and $14.1 \pm 2.1$ min respectively $P<0.05)$. All manually sutured grafts remained in place and partial suture dehiscence with incomplete occlusion of the internal inguinal ring was observed in two stapled grafts. Non-severe complications were observed trans or postoperatively. One synechiae and three omental adhesions were observed by laparoscopic control on day 77 , but without clinical relevance in the evaluated period. The use of homologous pericardium grafts was effectiveness to internal inguinal ring closure by laparoscopy. Mechanical suture was faster to perform than manual, but provided less satisfactory results concerning safety of graft fixation

Key words: equine, inguinal hernia, laparoscopy, herniorraphy.

RESUMO

A oclusão dos anéis inguinais é o tratamento indicado para evitar as hérnias inguinais comumente observadas nos equinos. O objetivo do trabalho é avaliar a eficácia do uso de enxerto de pericárdio homólogo para recobrimento do anel inguinal interno de equinos, fixado por laparoscopia, comparando a sutura manual e mecânica. Para tanto, foram utilizados seis equinos machos não castrados da raça Mangalarga com idade entre 3 e 12 anos. Os cavalos foram operados sob anestesia geral em posição de Trendelenburg com inclinação de $25^{\circ}$. Cinco portais laparoscópicos foram empregados. Enxertos de pericárdio homólogo, medindo $4 X 5 \mathrm{~cm}$, foram ancorados recobrindo os anéis inguinais internos esquerdo e direito, sendo em um dos lados fixado com sutura manual intracorpórea e o contralateral fixado com grampos, escolhidos por sorteio previamente ao procedimento, distribuido equitativamente. Os cavalos foram acompanhados por 11 semanas do periodo pósoperatório. O tempo cirúrgico, eventuais complicações trans ou pós-operatórias e a efetividade do procedimento foram avaliados $e$ analisados estatisticamente com nível de significância de 5\% $P<0,05$. Os procedimentos foram realizados sem complicações, com tempo médio requerido para realização da sutura manual e com grampos de 67,8 $\pm 15,3$ e 14,1 12,1 minutos, respectivamente, havendo diferença significativa $P<0,05$. Todos os implantes suturados manualmente levaram à oclusão do anel inguinal profundo, enquanto houve deiscência parcial da sutura, com incompleta oclusão do anel, em dois dos seis implantes fixados por sutura mecânica, na avaliação aos 77 dias. Não ocorreram complicações significativas no período trans ou pós-operatório, sendo observada a presença de uma sinéquia e três aderências de omento durante laparoscopia de controle aos 77 dias, porém sem relevância clínica no periodo estudado. O uso de pericárdio homólogo foi efetivo para oclusão do anel vaginal em equinos por laparoscopia. A sutura mecânica foi realizada em menor tempo, quando comparada à sutura manual, porém propiciou resultado menos satisfatório no que diz respeito à segurança da técnica para fixação do enxerto.

Palavras-chave: equino, hérnia inguinal, laparoscopia, herniorrafia.

\footnotetext{
'Departamento de Cirurgia, Faculdade de Medicina Veterinária e Zootecnia (FMVZ), Universidade de São Paulo (USP), 05508-270, São Paulo, SP, Brasil. E-mail: dspagnolo@usp.br. "Corresponding author.

"Departamento de Patologia, FMVZ, USP, São Paulo, SP, Brasil.

II'Departamento de Clínica Médica, FMVZ, USP, São Paulo, SP, Brasil.
} 


\section{INTRODUCTION}

Inguinal hernias have been well described in horses and are a common cause of colic due to intestinal strangulation mainly in stallions (SCHNEIDER et al., 1982; VAN DER VELDEN, 1988), however geldings (SCHNEIDER et al., 1982; BICKERS, et al., 1998) and mares (UMESTEAD, 1986) also can be affected less commonly. Inguinal hernias account $2.28 \%$ of reported equine gastrointestinal surgeries (COELHO et al., 2009) and 1,13 of every 1000 hospitalized horses suffer from inguinal herniation (SUPERLOCK et al., 1988). The jejunal and ileal segments of the small intestine are most commonly herniated (SCHNEIDER et al., 1982; FREEMAN, 2006). Inguinal herniation of the bladder (COUTSY et al., 2010), omentum and colon have also been reported (ROBINSON \& CARMALT; 2009).

Inguinal herniation may occur following orchiectomy with or without ligation of the vaginal tunic; intestinal and omental evisceration have been reported in $4.8 \%$ and $2.8 \%$ of 568 colt submitted to orchiectomy without significative difference between open or closed technique (SHOENAKER et al., 2004).

Different surgical approaches have been described for correction of inguinal hernias and indication is based on clinical presentation. Laparotomy is indicated in cases suspected of bowel strangulation or when manual reduction is not possible, and should be followed by resection and anastomosis whenever the herniated segment is compromised. Strangulating inguinal hernias can also be corrected through the inguinal approach (FREEMAN, 2006). In either case, the vaginal ring cannot be obliterated and the risk of recurrence therefore persists.

The laparoscopic approach enables occlusion of the internal inguinal ring(MARIEN, 2001; BOENING et al., 2007; CARON \& BRAKENHOFF, 2008; WILDERJANS et al., 2009) and can be used to prevent recurrences following emergency surgical intervention. Laparoscopic hernioplasty is employed for internal inguinal ring occlusion. Intracorporeal manual or mechanically assisted sutures (FISCHER, 2002; CARON \& MEHLER; 2009; REAGLE et al., 2013) with or without associated implants (FISCHER, 2002) can be performed. Fixation of peritoneal flaps in the recumbent (BOENING et al., 2007) or standing horse (WILDERJANS et al., 2009) has also been described. The biological implants as pericardium and other biological membranes are easy to obtain, have good elasticity and resilience (ALVARENGA, 1977) besides to be biocompatible with the intraabdominal environment. Homologous pericardium grafts have been implanted experimentally to cover intestinal lesions in horses without complications (BELLENZANI et al., 2004).

The aim of this study was to evaluate the use of homologous pericardium grafts for internal inguinal ring closure in horses, comparing mechanical or manual laparoscopic suture.

\section{MATERIALS AND METHODS}

\section{Experimental design}

Six healthy intact male Mangalarga breed horses aged 5.3 \pm 3.4 years and weighing $363.33 \pm 76.59 \mathrm{~kg}$ were used in this study. Horses were submitted to laparoscopic procedure for bilateral homologous pericardium implant fixation covering the internal inguinal rings using manual or mechanical suture. Daily clinical assessment during the experimental period was performed. After 11 weeks, horses were reoperated for graft evaluation on the implant place. The time required to close the vaginal ring using either manual or mechanical suture was documented and compared. Respective effectiveness and related intra and postoperative complications, as difficult of triangulation, handling of implant, suture execution were analyzed. Data were compared using Repeated Measures ANOVA (analysis of variance) and the Tukey test. Statistical analyses were performed using InstatGraphpad software. The level of significance was set at $5 \% \mathrm{P}<0.05$.

\section{Implant preparation}

Homologous pericardium was harvested, prepared and stored in $98 \%$ glycerin solution as described by ALVARENGA (1977). Grafts measuring $4 \times 5 \mathrm{~cm}$ were rehydrated in $0.9 \%$ saline solution for 15 minutes before intra-abdominal implantation.

Surgical technique

Horses were operated in dorsal recumbency under general anesthesia following food and water withdrawal ( $24 \mathrm{~h}$ and $12 \mathrm{~h}$ respectively). The ventral abdominal area was clipped, aseptically prepared and draped. Five portal laparoscopic approach was employed (Figure 1A).

After a midline incision, a $10 \mathrm{~mm}$ blunt trocar was inserted through the umbilicus for the introduction of a $10 \mathrm{~mm}, 30 \mathrm{~cm}$ length and $0^{\circ}$ laparoscope. Pneumoperitoneum was achieved with warm carbon dioxide and controlled $(8 \mathrm{mmHg})$ intraabdominal pressure.

Horses were then placed in $25^{\circ}$ Trendelenburg position and the four remaining trocars inserted under direct visualization to create the 


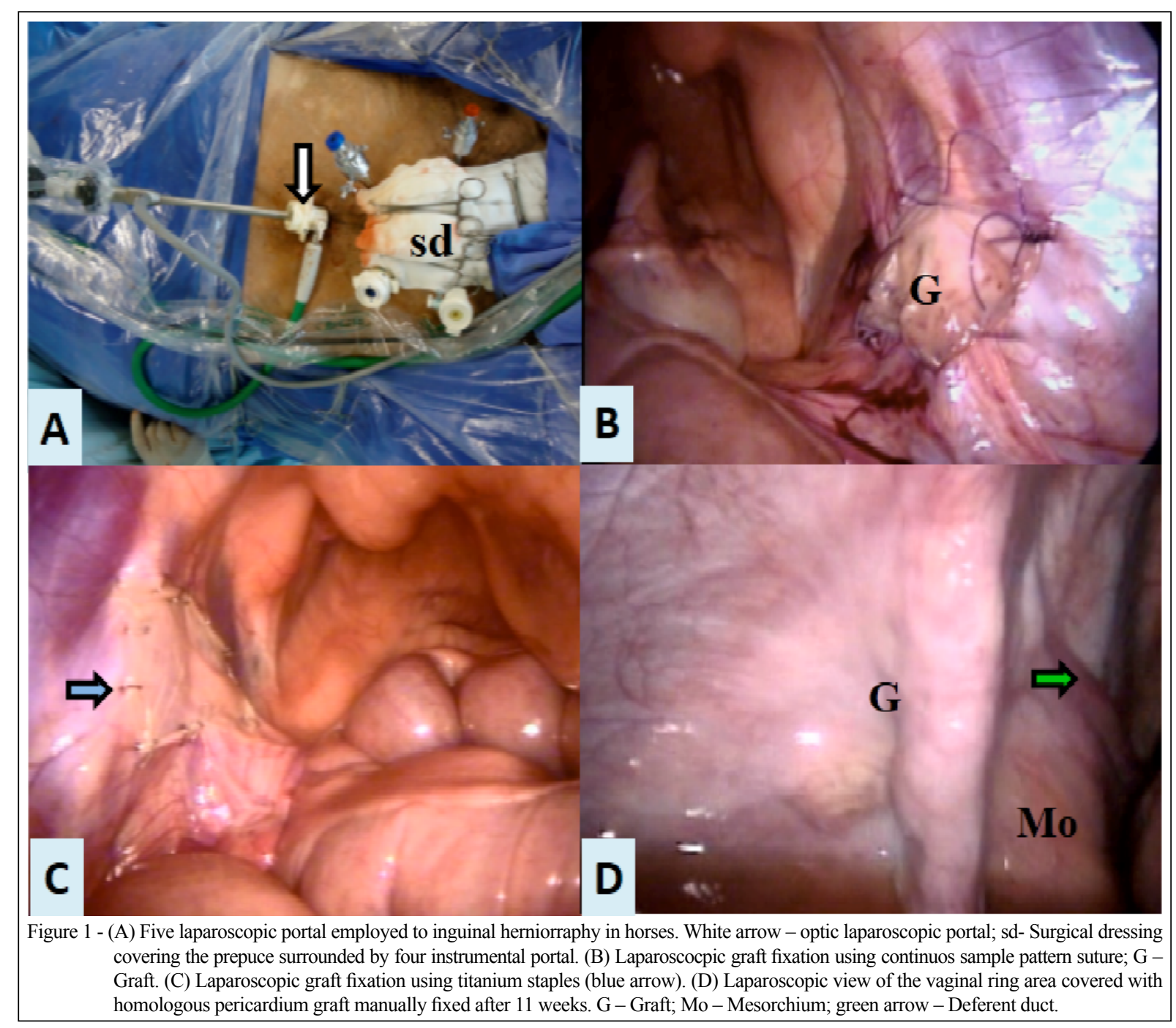

required instrument access, with two trocars (10 and $5 \mathrm{~mm}$ respectively) positioned $8 \mathrm{~cm}$ apart on either side of the prepuce. Pericardium grafts were introduced through the $10 \mathrm{~mm}$ trocar and placed over the vaginal rings so as to cover the opening of the inguinal canal using laparoscopic Kelly forceps. Local neurovascular structures were preserved. Grafts were anchored to the fibrous fascia of the internal abdominal oblique muscle, parietal peritoneum and mesorchium. Left and right vaginal rings were randomly selected for graft fixation with manual or mechanical suture. Manual intracorporeal suture was performed with 2-0 absorbable polyglecaprone 25 in a simple continuous pattern using laparoscopic needle holder and Kelly forceps in all four edges of implants (Figure 1B); mechanical suture was performed using laparoscopic Kelly forceps and disposable endostapler (Multifire Endo Hernia, Ethicon Endo Suture) (Figure 1C).
The abdominal cavity was then depressurized and portals closed with 0 and 2-0 monofilament nylon (external fascia of the rectus abdominal muscle and skin respectively) in a simple interrupted pattern. Horses were treated with sodium ampicillin $\left(20 \mathrm{mg} \mathrm{kg}^{-1} \mathrm{IV}\right)$ prior to surgery and flunixin meglumine $\left(1.1 \mathrm{mg} \mathrm{kg}^{-1} \mathrm{IV}\right)$ prior of surgery and once daily during the first three postoperative days.

\section{RESULTS}

To execute the implant fixation using the intracorporeal suture the mean time required to complete the manual and mechanical suture procedures differed significantly, being $67.3 \pm 15.3$ and $14.1 \pm 2.1$ minutes respectively; $\mathrm{P}<0.05$. The laparoscopic techniques coursed without complications, but the intracavitary handling of implants was laborious. 
In postoperative period all horses showed apathy, decreased appetite and increased heart and respiratory rates during the first $24 \mathrm{~h}$ following surgery. Two horses displayed signs of abdominal discomfort that responded to NSAID administration.

At laparoscopic evaluation on D77 the pericardium membrane was not clearly distinguishable and only the presence of healing tissue overlaid with parietal peritoneum could be visualized on previously fixed implant place. Exudate, dark areas or other changes suggesting of active inflammation or graft rejection were absent.

All manually sutured grafts remained in place and were embedded in the surrounding tissues and overlaid with peritoneum (Figure 1D). Mechanically anchored grafts remained in place in four cases, with partial migration and incomplete occlusion of the vaginal ring in the remaining two. Local adhesions were observed in three horses. In two cases, the omentum had adhered to the manually sutured graft. In the remaining case, synechiae had formed between the caudal edge of the manually sutured inguinal ring and the large colon, while omental adhesion were observed on the contralateral (mechanically sutured) ring.

\section{DISCUSSION}

The use of homologous pericardium to cover the internal inguinal ring fixed through laparoscopic suture is a safe and effective option to close the opened inguinal canal. The implant presents good resistance during surgical manipulation without tears or perforations by instruments and adequate tension to fixation. However excessive mobility of the biological membrane made both suture techniques difficult, and constant repositioning was required during the suture procedure.

Although manually sutured grafts remained in place, manual sutures were more time consuming to perform. Average time required for internal inguinal ring closure using simple interrupted intracorporeal sutures in horses suffering from inguinal herniation was reported to be 110 minutes (CARON \& BRAKENHOFF, 2008). In a different study (BOENING et al., 2007), the internal inguinal ring closure with peritoneal grafts was achieved in 45 minutes; according to authors of that study, suture time may be reduced further to 25 minutes if only two simple interrupted stiches are used. In this trial, average time required to suture one graft was 67.83 minutes; therefore, mean manual suture time was within the expected time frame and may be further decreased with training, already the surgeons have made training previous, but have few experience with laparoscopic manual suture. The laparoscopic stapling device (Endo Hernia multifire $0^{\circ}$ ) was easy to apply and facilitated graft positioning. Mechanical sutures were approximately four times faster to perform; however, 14 to 16 staples were required per graft, adding to overall surgical costs. Two out of six mechanically anchored grafts underwent partial migration, possibly due to the insufficient strength of small-sized staples to resist local tension. However, titanium staples of similar size have been successfully employed for standing laparoscopic peritoneal flap hernioplasty in 30 adult horses, with recurrence of inguinal herniation in 4 out of 30 operated (WILDERJANS et al., 2012). In our opinion, the mixed mechanical and manual suture can facilitate the implant position and reduce the surgical time, providing more safety procedure. Laparoscopic surgery enables good visualization and adequate access to the inguinal area when performed in the dorsal recumbent Trendelenburg position (SILVA et al., 1997; FISCHER, 2002). In this study, the five portals technique provided satisfactory surgical access for bilateral inguinal occlusion and good position to the surgeon. A similar technique with portals positioned ipsilateral to the inguinal ring selected has been previously proposed (CARON \& BRAKENHOFF, 2008).

Regarding the changes of the physical parameters of the horses during the initial postoperative period we can relate to the pneumoperitoneum and surgical trauma (VOLZ et al., 1996; LATIMER et al., 2003), being that the clinical changes were controlled on first two days and using NSAIDs.

In this study, grafts were no longer visible at 11 weeks regardless of the grafting technique employed. Complete integration of biological membrane with surrounding tissues is therefore suggested. Complete incorporation of equine pericardium 60 days post-grafting was previously reported in diaphragmatic reconstruction in dogs (RANZANI et al., 1990). Omental adhesions resulted from both grafting techniques studied. Adhesions were devoid of clinical significance during the followup period and possibly reflected the natural tendency of the omentum to adhere to intra-abdominal lesions or foreign material. Most adhesions in this study were associated with manual sutures and may be partially attributed to increased surgical manipulation or the presence of exposed suture material in the abdominal cavity. However, adhesions were not reported in previous studies involving manual fixation of intra- 
abdominal homologous pericardium grafts in horses (BELLENZANI et al., 2004). Further clinical studies are warranted to determine the value of biological membranes as alternative grafting materials for laparoscopic inguinal hernioplasty in horses. Different grafting techniques for different inguinal hernia presentations, as well as the long-term impact on anatomical structures related and unrelated to the reproductive tract should be analyzed.

\section{CONCLUSION}

In this study, laparoscopic implantation of homologous pericardium grafts enabled satisfactory occlusion of the internal opening of the inguinal canal. Superior holding ability and lower costs were achieved with manual graft suture, despite longer surgical time. Lack of relevant postoperative complications and satisfactory healing, with complete incorporation of the biological membrane into the surrounding tissues, support the indication of homologous pericardium grafts in laparoscopic inguinal hernioplasty in horses.

\section{ACKNOWLEDGMENT}

Fundação de Ampara à Pesquisa do Estado de São Paulo (FAPESP) (Nº 2008/07841-2).

\section{BIOETHICS AND COMMITTE APPROVAL \\ BIOSSECURITY}

This study was approved by Ethics Committee on Animal Research of the Escola de Medicina Veterinária e Ciência Animal of the Universidade de São Paulo (USP) (protocol number 818/2005).

\section{REFERENCES}

BELLENZANI, M.C.R. et al. Evaluation of the healing of surgically created small colon serosal lesion in horses, treated by homologous pericardium implantation: an experimental study. Journal of Equine Veterinary Science, v. 24, n. 12, p. 535-539, 2004. Available from: <http://ac.els-cdn.com/ S0737080604004435/1-s2.0-S0737080604004435>. Accessed: Jul. 10, 2014. doi: 10.1016/j.jevs.2004.11.007.

BICKERS, R.J. et al. Acquired inguinal hernia in a gelding, Equine Practice, v. 20, n. 10, p. 28-29, 1998. Available from: $<$ http://aims.fao.org/serials/c 8e8b4b90>. Accessed: Jun, 3, 2014. PMIF: US1997091452.

BOENING, J.K. et al. Laparoscopy hernioplasty in recumbent horses using transposition of a peritoneal flap. Veterinary Surgery, v. 36, n. 6, p. 557-562, 2007. Available from: <http://onlinelibrary. wiley.com/doi/10.1111/j.1532-950X.2007.00282.x/epdf> Accessed: Jul, 5, 2014. doi: 10.1111/j.1532-950X.2007.00282.x.

CARON, J.P.; BRAKENHOFF, J. Intracorporeal suture closure of the internal inguinal and vaginal rings in foals and horses. Veterinary Surgery, v. 37 , n. 2 , p. $126-131,2008$. Available from: <http://
onlinelibrary.wiley.com/doi/10.1111/j.1532-950X.2007.00366.x/ epdf>. Accessed:Jul, 5, 2014. doi: 10.1111/j.1532-950X.2007.00366.x.

CARON, J.P.; MEHLER, S.J. Laparoscopic mesh incisional hernioplasty in five horses. Veterinary Surgery, v. 38, n. 3, p. 318-325, 2009. Available from: <http://onlinelibrary.wiley.com/ doi/10.1111/j.1532-950X.2009.00511.x/epdf>. Accessed: Jul, 5, 2014. doi: 10.1111/j.1532-950X.2009.00511.x.

COELHO, C.S. et al. Retrospective study of inguinal hernia in horses: 28 cases. Retrospective study of inguinal hernia in horses: 28 cases. In: $11^{\text {th }}$ INTERNATIONAL CONGRESS OF THE WORLD EQUINE VETERINARY ASSOCIATION. Proceedings of $11^{\text {th }}$ International Congress of the World Equine Veterinary Association. Guarujá-São Paulo 2009

COUSTY, M. et al. Inguinal rupture with herniation of the urinary bladder through the scrotal fascia in a Shetland pony foal. Equine Veterinary Education, v. 22, n. 1, p. 3-6, 2010. Available from: $<$ http://onlinelibrary.wiley.com/doi/10.2746/095777309X462/ abstract $>$. Accessed: Jun, 23, 2014. doi: 10.2746/095777309X462.

FISCHER, A.T. et al. Laparoscopic inguinal herniorraphy in two stallions. Journal American Veterinary Medical Association, 1995; 207,: p.1599-1601, 1995.

FISCHER, J.R. AT: Laparoscopic inguinal herniorrhaphy. In: _ Equine diagnostic and surgical laparoscopy. Philadelphia: W.B.Saunders, 2002, p. 171-180.

FREEMAN, D. Small intestine. In: AUER, J.A.; STICK, J.A. Equine Surgery (3.eds). St. Louis: Saunders, 2006. p. 401-436.

LATIMER, F.G. et al. Cardiopulmonary, blood and peritoneal fluid alterations associated with insufflations of the carbon dioxide in standing horses. Equine Veterinary Journal, v. 35, n.3, p. 283-290, 2003. Available from: <http://www.ncbi.nlm. nih.gov/pubmed/12755432>. Accessed: Jan, 10, 2015. doi: $10.2746 / 042516403776148273$

MARIËN, T. Standing laparoscopic herniorrhaphy in stallions using cylindrical polypropylene mesh prosthesis. Equine Veterinary Journal, v. 33, n. 1, p. 91-99, 2001. Available from: $<$ http://www.ncbi.nlm.nih.gov/pubmed/11191617>. Accessed: Jun 3, 2014 doi: 10.2746/042516401776767476.

RANZANI, J.J.T. et al. Implant of equine pericardium in diaphragmatic lesions in dog. Brazilian Journal Resarch Animal Science, v. 27, n. 1, p. 63-70, 1990. Available from: <http://www. revistas.usp.br/bjvras/article/viewFile/51839/55892>. Accessed: Aug, 7, 2014. doi: 10.11606/issn.0000-0000.27165-73.

REAGLE, C.A. et al. Use of a barbed suture for laparoscopic closure of the internal inguinal rings in a horse. Journal American Veterinary Medical Association, vol. 242, n.2, p. 249-253, 2013. Available from: < http://www.ncbi.nlm.nih.gov/pubmed/23276104>. Accessed: Nov. 10, 2014 doi: 10.2460/javma.242.2.249.

ROBINSON, E.; CARMALT, J.L. Inguinal herniation of the ascending colon in a 6-month-old standardbred colt. Veterinary Surgery, v. 38, n. 8, p. 1012-1013, 2009. Available from: $<$ http://onlinelibrary. wiley.com/doi/10.1111/j.1532-950X.2009.00595.X/epdf>. Accessed: jun, 23, 2014. doi: 10.1111/j.1532-950X.2009.00595.x.

SCHNEIDER, R.K. et al. Acquired inguinal hernia in the horse: a review of 27 cases, Journal American Veterinary Medical Association, v. 180, n. 3, p. 317-320, 1982. 
SHOEMAKER, R. et al. Routine castration in 568 draught colts: incidence of evisceration and omental herniation. Equine Veterinary Journal, v. 36, n. 4, p. 336-340, 2004. Available from: $<$ http://www.ncbi.nlm.nih.gov/pubmed/15163041>. Accessed: Jun, 23 , 2014. doi: 10.2746/0425164044890625.

SILVA, L.C.L.C. et al. Laparoscopic study of horse abdominal viscera by ventral midleline approach. Brazilian Journal of Veterinary Research and Animal Science, v. 34, n. 4, p. 211-217, 1997. Available from: <http://www.revistas.usp.br/bjvras/article/ viewFile/50296/54409>. Accessed: Nov. 10, 2014. doi: 10.11606/ issn.2318-3659.v34i4p211-217.

SPURLOCK, G.H.; ROBERTSON, J.T. Congenital inguinal hernias associated with a rent in the common vaginal tunic in five foals. Journal Americcan Veterinary Medical Association, v. 193, n. 9, p. 1087-1088, 1988.

UMESTEAD, J.A. et al. Inguinal ring herniation in a female Shetland pony. Compendium Continued Education Practice Veterinary, v. 8, p. 164-165, 1986.

VAN DER VELDEN, M.A. Ruptured inguinal hernia in new-born colt foals: a review of 14 cases. Equine Veterinary Journal, v. 20 , n. 3, p. 178-181, 1988. Available from: <http://onlinelibrary.wiley. com/doi/10.1111/j.2042-3306.1988.tb01492.x/pdf>. Accessed: Jun, 3, 2014. doi: 10.1111/j.2042-3306.1988.tb01492.x.

VOLZ, J. et al. Pathophysiologic features of a pneumoperitoneum at laparoscopy: A swine model. American Journal of Obstetrics and Gynecology, V. 174, n. 1, p. 132-140, 1996. Available from: <http:// www.sciencedirect.com/science/article/pii/S000293789670385X>. Accessed: Oct, 19, 2014. doi: 10.1016/S0002-9378(96)70385-X.

WILDERJANS, H. et al. Standing laparoscopic approach in the horse for internal inguinal ring reduction using flap peritoneal. In: $11^{\text {th }}$ INTERNATIONAL CONGRESS OF THE WORLD EQUINE VETERINARY ASSOCIATION. Proceedings $\mathbf{1 1}^{\text {th }}$ International Congress of the World Equine Veterinary Association of the $11^{\text {th }}$ International Congress of the World Equine Veterinary Association. Guarujá - São Paulo: - SP, Brasil, 2009.

WILDERJANS, H. et al. Standing laparoscopic peritoneal flap hernioplasty technique for preventing recurrence of acquired strangulating inguinal herniation in stallions. Veterinary Surgery, v. 41, n.2 p.292-299, 2012. Available from: <http://onlinelibrary. wiley.com/doi/10.1111/j.1532-950X.2011.00914.x/epdf $>$. Accessed: Nov. 10, 2014. doi: 10.1111/j.1532-950X.2011.00914.x. 